\title{
Isolated Spontaneous Pectoralis Minor Tendon Rupture in a Patient with Chronic Renal Failure
}

\author{
Kronik Böbrek Yetmezlikli Hastada Spontan Izole Pektoralis Minör Tendon Rüptürü
}

Merve Örücü1, Șehim Kutlay' ${ }^{1}$, Seçilay Güneș ${ }^{1}$, Haydar Gök ${ }^{1}$

Ankara University Faculty of Medicine, Department of Physical Medicine and Rehabilitation.
Received: May 17,2016• Accepted: June 23, 2016

\section{Corresponding Author}

Merve Örücü, M.D,

E-mail: drmerveorucu@hotmail.com

Tel: +903125082822

Fax: +903123094132

Ankara University Faculty of Medicine Department of Physical Medicine and Rehabilitation 06100 Sihhiye Ankara TURKEY

\begin{abstract}
Isolated rupture of the pectoralis minor tendon is extremely rare and has been reported 3 times in 4 patients. This article describes the first case of an isolated spontaneous pectoralis minor tendon tear in an endstage renal disease (ESRD) patient undergoing long-term hemodialysis and with a previous history of bilateral rupture of the quadriceps tendons. He presented with left anterior shoulderand chest wall pain with direct tenderness on palpation over the coracoid. Magnetic resonance imaging revealed an isolated tear of the pectoralis minor tendon with an intact pectoralis major tendon. The patient returned to full activities after conservative management. Although rare, the diagnosis of pectoralis minor tendon rupture should be considered in ESRD patients who present with anterior shoulder pain in the absence of an antecendent trauma.

Key Words: End-Stage Renal Disease, Pectoralis Minor, Tendon Rupture, Hemodialysis

Pektoralis minör tendonunun izole rüptürü son derece nadirdir ve 4 hastada 3 kez bildirilmiștir. Bu makale uzun süredir hemodiyalize giren ve bilateral kuadriseps tendonlarında rüptür hikayesi olan, son dönem böbrek yetmezliği (SDBY) bulunan hastadaki ilk izole spontan pektoralis minör tendon rüptürüdür. Hasta sol ön omuz ve korakoid üzerinde palpasyonla hassasiyet veren göğüs ön duvarı ağrısıyla bașvurdu. Manyetik rezonans görüntülemede sağlam pektoralis major tendonuyla birlikte pektoralis minör tendonu izole rüptürü mevcuttu. Hasta konservatif tedavi sonrası eski aktivite düzeyine döndü. Nadir olmakla birlikte pektoralis minör tendon rüptürü tanısı ön omuz ağrısıyla bașvuran, öncesinde travma öyküsü olmayan SDBY hastalarında düșünülmelidir.
\end{abstract}

Anahtar Sözcükler: Son Dönem Böbrek Yetmezliği, Pektoralis Minör, Tendon Rüptürü, Hemodiyaliz

Spontaneous rupture of tendons (quadriceps, Achilles and patellar tendon) is a clinical entitHy that is commonly reported to occur during the course of chronic diseases including the endstage renal disease (ESRD), diabetes mellitus, systemic lupus erythematosus and treatment with corticosteroids, statins and the fluoroquinolone antibiotics (1-4). Isolated spontaneous rupture of the pectoralis minor tendon without the pectoralis major tendon tear is extremely rare (5-8). Those reported cases were healthy people and had an antecedent trauma. Literature search on PubMed and MEDLINE revealed no reported case of isolated spontaneous pectoralis minor tears in chronic diseases. Herein, we report an isolated spontaneous rupture of the pectoralis minor tendon in an ESRD patient undergoing longterm hemodialysis and with a previ- ous history of bilateral rupture of the quadriceps tendons.

\section{Case Report}

A-59-year-old male presented with left anterior shoulder and chest wall pain. His pain worsened on abduction and extension of the arm beyond the scapular plain. He had type 1 diabetes mellitus, ESRD secondary to diabetic nephropathy and has been on hemodialysis for the last 9 years. Simultaneous rupture of quadriceps tendons occurred after a minor trauma within the last year. He underwent a surgical treatment. He had no history of trauma, injury or treatment with the quinolone antibiotics, and/or steroids, but atorvastatin with a $20 \mathrm{mg}$ dose per day. On detailed questioning, he reported that he had to use a wheelchair for three weeks after the surgical repair of tendon rupture. 
On physical examination, there was a significant atrophy of the left shoulder girdle muscles (Figure 1), bilateral quadriceps muscles (Figure 2) and a localized tenderness to palpation over the coracoid process anteriorly. $\mathrm{He}$ had a $20^{\circ}$ limitation of flexion and $30^{\circ}$ limitation of abduction at the left shoulder. Neurological examination showed a mild weakness in the shoulder flexion, abduction and external rotation movements. He was ambulating with a walker.

Laboratory tests revealed BUN $85 \mathrm{mg} / \mathrm{dL}$ (6-20); creatinine $10,63 \mathrm{mg} / \mathrm{dL}(0,7-$ 1,2); ALP $721 \mathrm{U} / \mathrm{L}$ (40-129), calcium $8,1 \mathrm{mg} / \mathrm{dL}$ (8,6-10,2); phosphate 7,6 $\mathrm{mg} / \mathrm{dL}(2,7-4,5)$; intact Parathyroid hormone (iPTH) 788,5 pg/mL(876)and 25-OH vitamin D $6,5 \mu \mathrm{g} / \mathrm{L}$ (winter:10-60, summer: 20-120).

Plain radiographs of the left shoulder showed acromioclavicular joint degeneration with no evidence of a fracture or dislocation (Figure 3). Magnetic resonance imaging revealed an isolated tear of the pectoralis minor tendon from the coracoid process with a slight retraction and ede$\mathrm{ma}$ in the muscle (Figure 4). No tear of the pectoralis major tendon was identified.

A conservative treatment course including physical therapy and rehabilitation program combined with a nonsteroidal anti-inflammatory drug was started. The program consisted of the cross-friction massage, TENS and the scapular stabilization exercises with avoidance of abduction and active adduction. After 4 weeks of treatment, there was a significant improvement of shoulder range of motion. He was able to return to his previous activity levels with a significant decrease in shoulder pain. The patient was considered to have resistant hyperparathyroidism (based on the definition as an iPTH level of $600 \mathrm{pg} / \mathrm{mL}$ or greater after 6 months of increasing doses of IV calcitriol and the use of calcimimetic agents). Parathyroidectomy had been recommended to him, but he had refused.

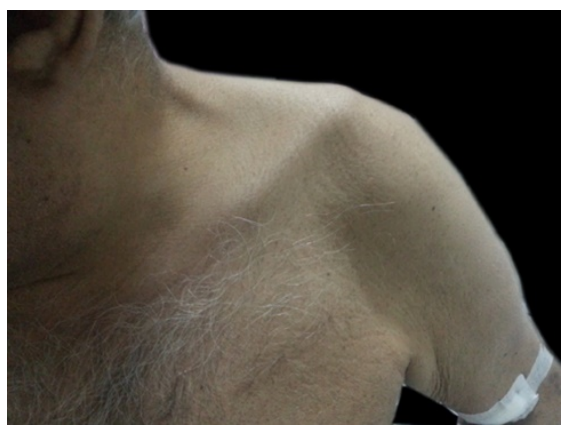

Figure 1. Photograph shows a significant atrophy of the left shoulder girdle muscles

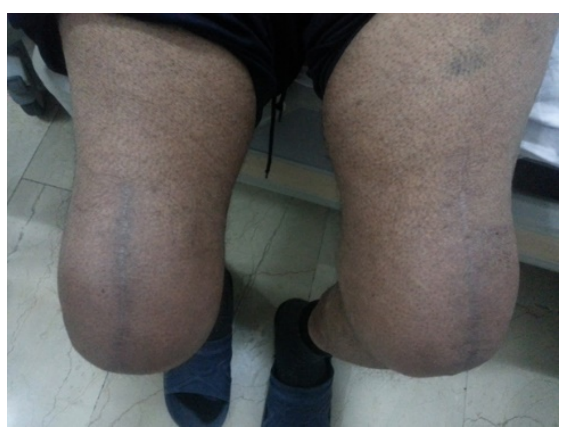

Figure 2. Photograph shows a significant atrophy of the bilateral quadriceps muscles.

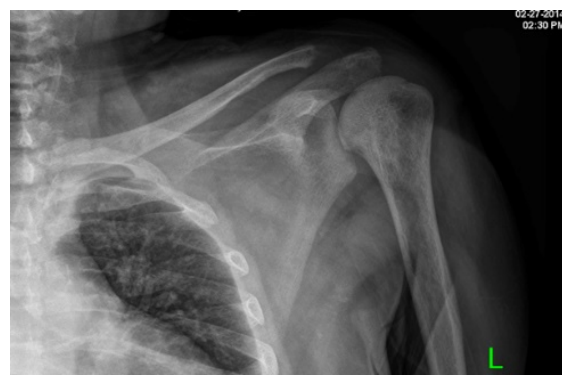

Figure 3. Plain radiograph of the left shoulder showing acromioclavicular joint degeneration with no evidence of a fracture or dislocation.

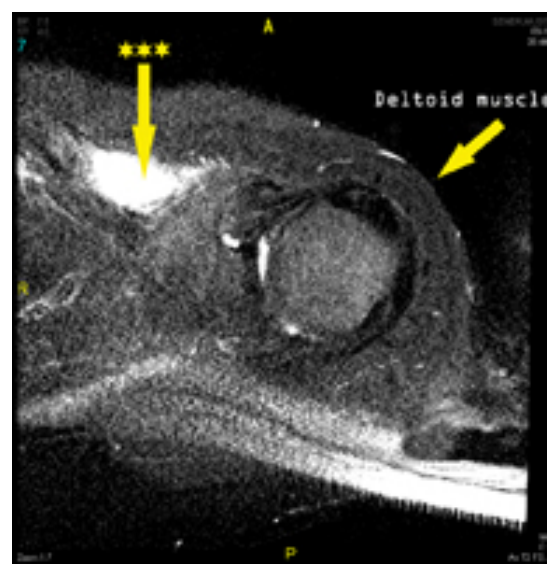

Figure 4. A) Axial T2-weighted magnetic resonance image showing high signal at the pectoralis minor muscle tendon junction (asterisk);

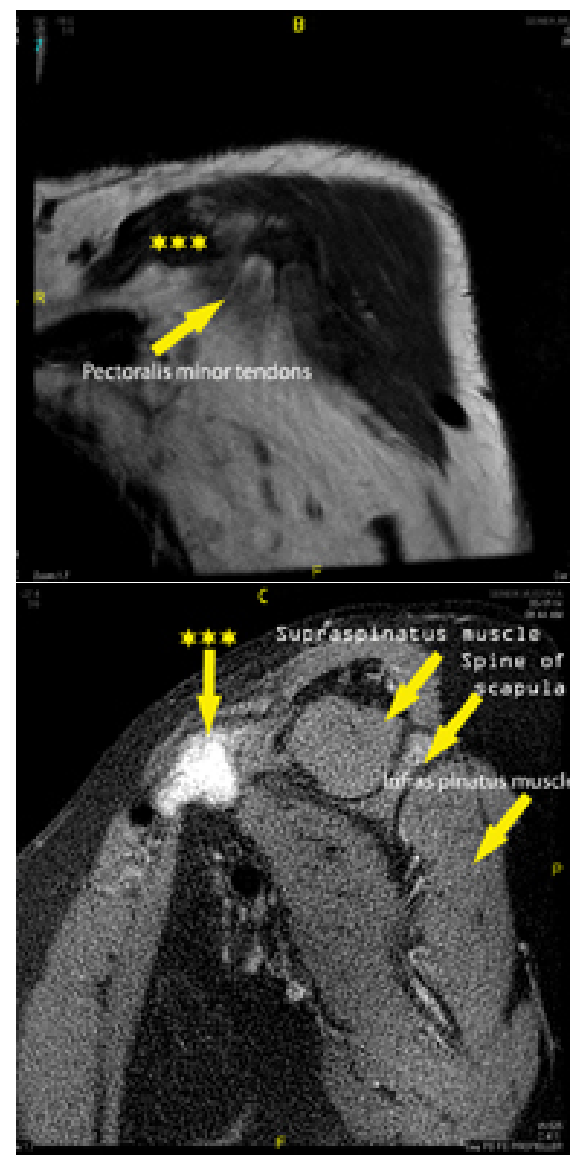

Figure 4. B)Sagittal T2-weighted magnetic resonance image showing significant edema (asterisk) in the pectoralis minor muscle detachment of the tendon from the coracoid; C) Coronal T1 weighted magnetic resonance image showing absence of one of the pectoralis minor tendons (asterisk) which is the same place shown hyperintense in T2 weighted images.

\section{Discussion}

This is the first reported case of an isolated spontaneous pectoralis minor tendon rupture in a patient with ESRD. The rupture occurred without an antecedent direct trauma to the shoulder.

The pectoralis minor muscle arises from the upper margins and outer surfaces of the third, fourth, and fifth ribs, near their cartilages and from the aponeuroses covering the intercostalis. The tendon of insertion commonly extends over the coracoid process to the greater tubercle along with the conjoint tendon. It's been thought that the overlying pectoralis major muscle protects the pectoralis 
minor muscle from direct anterior traumas to shoulder (6). Therefore, isolated rupture of the pectoralis minor muscle tendon is extremely rare with only 4 cases that were reported in the literature (5-8). All cases involved healthy sports players and had an antecedent direct trauma. The presenting case however, had an ESRD and has been on the long-term hemodialysis and atorvastatin treatment. He developed a spontaneous isolated pectoralis minor tendon rupture following serial rupture of quadripces muscle tendons in the course of disease.

The quadriceps, Achilles, patellar, triceps, biceps, supraspinatus, and subscapularis tendon ruptures in patients with chronic renal failure have been previously reported in the literature (9-11). Possible factors associated with tendon rupture in patients with chronic renal failure are uremic toxins, sec-

\section{REFERENCES}

1. Jones N, Kjellstrand CM. Spontaneous tendon ruptures in patients on chronic dialysis, Am J Kidney Dis. 1996; 28:861-866.

2. Shah MK. Simultaneous bilateral quadriceps tendon rupture in renal patients. ClinNephrol. 2002;58:118-121.

3. Matokovic D, Matijasevic B, Petric P, Crnkovic T, Skorvaga S. A case report of spontaneous concurrent bilateral rupture of the quadriceps tendons in a patient with chronic renal failure. TherApher Dial. 2010;14:104.

4. Celik EC, Ozbaydar M, Ofluoglu D, Demircay E. Simultaneous and spontaneous bilateral quadriceps tendons rupture. Am J Phys Med Rehabil. 2012;91:631634.

5. Li X, Gorman MT, Dines JS, Limpisvasti $\mathrm{O}$, Isolated tear of the pectoralis minor tendon in a high school football player.Orthopedics. 2012;35:e1272-1275.

6. Kalra K, Neri B. Isolated pectoralis minor tendon tear in a professional ice hockey player-radiographic findings and presentation. Skeletal Radiol. 2010; 39(12):1251-1253. ondary amyloidosis, chronic metabolic acidosis, secondary hyperparathy

roidism and hemodialysis (2,12-14). Other factors that may predispose to tendon injury in chronic renal failure patients include corticosteroid treatment, statins, and fluoroquinolone antibiotics $(4,15,16)$. In the current case, secondary hyperparathyroidism, long-term hemodialysis and concomittant statin use are the major predisposing factors for the spontenous tendon rupture. It was thought that bone resorption at the tendon insertion sites caused by the secondary hyperparathyroidism plays a significant role in the pathogenesis of tendon rupture (14). There was no history of any corticosteroid or fluoroquinolone antibiotics use before the tendon rupture in this case.

Ultrasonography and magnetic resonance imaging have previously been shown to be helpful in the diagnosis of rup- tures of the pectoralis minor. Axial, sagittal and coronal T1-weighted MRIs of the shoulder are usually recommended to confirm the diagnosis. Axial T2-weighted MRIs might help to reveal the pathology secondary to surrounding edema around the medial corocoid that extends into the muscle belly (12). In the current case, MRI was used to confirm the pectoralis minor tendon rupture. It was also able to demonstrate that the pectoralis major was intact.

In conclusion, although isolated spontaneous rupture of the pectoralis minor tendon is extremely rare, it should be considered in ESRD patients presenting with anterior shoulder pain. Diagnosis should be made on the basis of history, physical examination, and MRI findings.

ceps tendon rupture in a patient with hyperparathyroidism undergoing long-term hemodialysis: A case report and literature review. J Int Med Res. 2013; 41: 1378.

8. Zvijac JE, Zikria B, Botto-van Bemden A. Isolated tears of pectoralis minor muscle in professional football players: a case series. Am J Orthop (Belle Mead NJ). 2009; 38:145-147.

9. Soo I, Christiansen J, Marion D, Courtney M, Luyckx VA. Sequential rupture of triceps and quadriceps tendons in a dialysis patient using hormone supplements. Clin Nephrol. 2011; 75 Suppl 1:20-23.

10. Muratli HH, Celebi L, Hapa O, Biçimoğlu A. Simultaneous rupture of the quadriceps tendon and contralateral patellar tendon in a patient with chronic renal failure. J Orthop Sci. 2005; 10:227-232.

11. Ureten K, Oztürk MA, Ozbek M, Unverdi S, Spontaneous and simultaneous rupture of both Achilles tendons and pathological fracture of the femur neck in a patient receiving long-term hemodialysis. IntUrolNephrol. 2008;40:1103-1106.

12. Mao-Feng Gao, Hui-Lin Yang, WeiDong Shi. Simultaneous bilateral quadri-
13. Kurer MH, Baillod RA, Madgwick JC. Musculoskeletal manifestations of amyloidosis. A review of 83 patients on hemodialysis for at least ten years. J Bone Joint Surg (Br). 1991; 73:271-276.

14. Kim BS, Kim YW, Song EK, Seon JK, Kang KD, Kim HN. Simultaneous bilateral quadriceps tendon rupture in a patient with chronic renal failure. Knee Surg Relat Res. 2012;24:56-59.

15. Tsourvakas S, Gouvalas K, Gimstas C, et al. Bilateral and simultaneous rupture of the triceps tendons in chronic renal failure and secondary hyperparathyroidism. Arch Orthop Trauma Surg. 2004; 124:278-280.

16. Palmer S, Birks C, Dunbar J, Walker R. Simultaneous multiple tendon ruptures complicating a seizure in a haemodialysis patient. Nephrology. 2004; 9: 262-264. 
